\title{
Wheat Puroindolines Enhance Fungal Disease Resistance in Transgenic Rice
}

\author{
Konduru Krishnamurthy, Carlotta Balconi, John E. Sherwood, and Michael J. Giroux \\ Department of Plant Sciences and Plant Pathology, Agricultural BioScience Facility, Montana State \\ University, Bozeman 59717-3150, U.S.A. \\ Submitted 15 February 2001; Accepted 11 June 2001.
}

\begin{abstract}
Antimicrobial peptides play a role in the immune systems of animals and plants by limiting pathogen infection and growth. The puroindolines, endosperm-specific proteins involved in wheat seed hardness, are small proteins reported to have in vitro antimicrobial properties. Rice, the most widely used cereal crop worldwide, normally does not contain puroindolines. Transgenic rice plants that constitutively express the puroindoline genes $\operatorname{pin} A$ and/or pinB throughout the plants were produced. PIN extracts of leaves from the transgenic plants reduced in vitro growth of Magnaporthe grisea and Rhizoctonia solani, two major fungal pathogens of rice, by 35 to $50 \%$. Transgenic rice expressing $\operatorname{pin} A$ and/or $\operatorname{pin} B$ showed significantly increased tolerance to $M$. grisea (rice blast), with a 29 to $54 \%$ reduction in symptoms, and $R$. solani (sheath blight), with an 11 to $22 \%$ reduction in symptoms. Puroindolines are effective in vivo in antifungal proteins and could be valuable new tools in the control of a wide range of fungal pathogens of crop plants.
\end{abstract}

Plants and animals produce antimicrobial peptides as part of their natural defense systems to control disease-causing microorganisms (Broekaert et al. 1992; Hancock and Scott 2000; Osbourn 1999). These peptides may act against bacteria and/or fungi and may be expressed constitutively or induced following infection. Plants contain numerous antimicrobial peptides that may be involved in protecting the plant from pathogens such as pathogenesis-related proteins, chitinases, $\beta$-1,3-glucanases, ribosome-inactivating protein, cysteine-rich antimicrobial peptides, $2 \mathrm{~S}$ albumins, defensins, thionins, and nonspecific lipid transfer proteins (nsLTPs) (Broekaert et al. 1992; Conceicao and Broekaert 1999; Datta and Muthukrishnan 1999; Fernandez de Caleya et al. 1972; Huynh et al. 1992; Leah et al. 1991; Roberts and Selitrennikoff 1986; Terras et al. 1992).

Corresponding author: J. E. Sherwood; E-mail: sherwood@montana.edu

Current address of K. Krishnamurthy: Department of Entomology and Plant Pathology, Oklahoma State University, 127 Noble Research Center, Stillwater 74978-3033, U.S.A.

Permanent address of C. Balconi: Istituto Sperimentale per la Cerealicoltura, Sezioni di Bergamo e Vercelli, Italy.
In vitro antimicrobial activity of the puroindoline proteins, PINA and PINB, against several fungal plant pathogens, has been reported (Dubreil et al. 1998). The puroindolines are found only in the Triticea and expressed specifically in endosperm tissue of developing seeds of wheat (Dubreil et al. 1998), oats (Tanchak et al. 1998), and barley (Beecher et al. 2001). The PIN proteins also are likely components of the wheat grain hardness locus (Giroux and Morris 1997; Giroux and Morris 1998).

The puroindolines are related structurally to several other plant proteins that have antimicrobial properties such as thionins and nsLTPs (Broekaert et al. 1997; Garcia-Olmeda et al. 1995). Some of these proteins have been shown to disrupt lipid bilayers, leading to cell death (Hill et al. 1991; Kagan et al. 1990; Thevissen at al. 1999). Like these proteins, PINA and PINB are small $(13 \mathrm{kDa})$, basic $(\mathrm{pI}>10)$, and cysteine rich, each having five disulfide bonds. An additional sequence present in PINA and PINB, which is not in other known plant antimicrobial proteins, is a hydrophobic tryptophan-rich domain that has been demonstrated to have lipid-binding properties (Dubreil et al. 1998). This property also might be expected to disrupt lipid bilayer membranes, contributing to the antimicrobial activity of the puroindolines.

Rice is the most important food crop worldwide, feeding over $50 \%$ of the world's population. Rice blast, caused by Magnaporthe grisea, is the most devastating disease of rice and highly variable with respect to host range and cultivar specificity (Ou 1985). Because of the instability of the blast fungus and the marked variability in pathogenicity in different strains of the organism, disease control through breeding has met only with partial success. Sheath blight, caused by Rhizoctonia solani, occurs throughout the rice-producing areas of the world and is second only to rice blast as the most economically important fungal disease of rice (Ou 1985). Attempts to control sheath blight with resistant cultivars have not been successful because of low levels of available host resistance. Transgenic rice plants, having enhanced resistance to rice blast and sheath blight, would be a significant advance over available germ plasm.

We transformed the rice cultivar M202 with pinA and/or $\operatorname{pin} B$ to determine whether the reported in vitro antifungal activity (Dubreil et al. 1998) also was effective in planta. Transgenic rice plants that expressed these genes constitutively 
throughout the plant were tested for disease reaction to $M$. grisea and $R$. solani.

The puroindoline genes $\operatorname{pin} A$ and $\operatorname{pin} B$ were isolated from RNA extracted from developing seeds of Chinese spring wheat (Krishnamurthy and Giroux 2001). Plasmids were constructed by fusing each pin gene with the constitutively expressed maize ubiquitin promoter. Three plasmids were constructed: one contained only the hygromycin phospho-transferase ( $h p t)$ gene that confers hygromycin resistance, a second contained $\operatorname{pin} A$, and the third contained $\operatorname{pin} B$. The three plasmids were co-transformed into callus tissue of rice cultivar M202 (Johnson et al. 1986), a short-season, medium-grain, highyielding California cultivar that is extremely susceptible to blast. Seeds from hygromycin-resistant plants were analyzed for the presence and endosperm-specific expression of the individual pin genes (Krishnamurthy and Giroux 2001). Four representative homozygous $\mathrm{T}_{2}$ lines, along with the wild-type M202 control, were selected from 40 independent transformants for further expression analysis. These included a line that only expressed $\operatorname{pin} A\left(\operatorname{pin}^{+} \mathrm{B}^{-}\right)$, one that only expressed $\operatorname{pin} B\left(\operatorname{pin}^{-} \mathrm{B}^{+}\right)$, one that expressed both $\left(\right.$ pin $\mathrm{A}^{+} \mathrm{B}^{+}$), and one that was hygromycin resistant but expressed neither $\operatorname{pin} A$ nor $\operatorname{pin} B\left(\operatorname{pin}^{-} \mathrm{B}^{-}\right)$. These lines are described by Krishnamurthy and Giroux 2001 as 91$29,97-5,97-1$, and 97-3, respectively. Each had a single or low copy number integration of the pin gene, and all were inherited as single loci (Krishnamurthy and Giroux 2001).
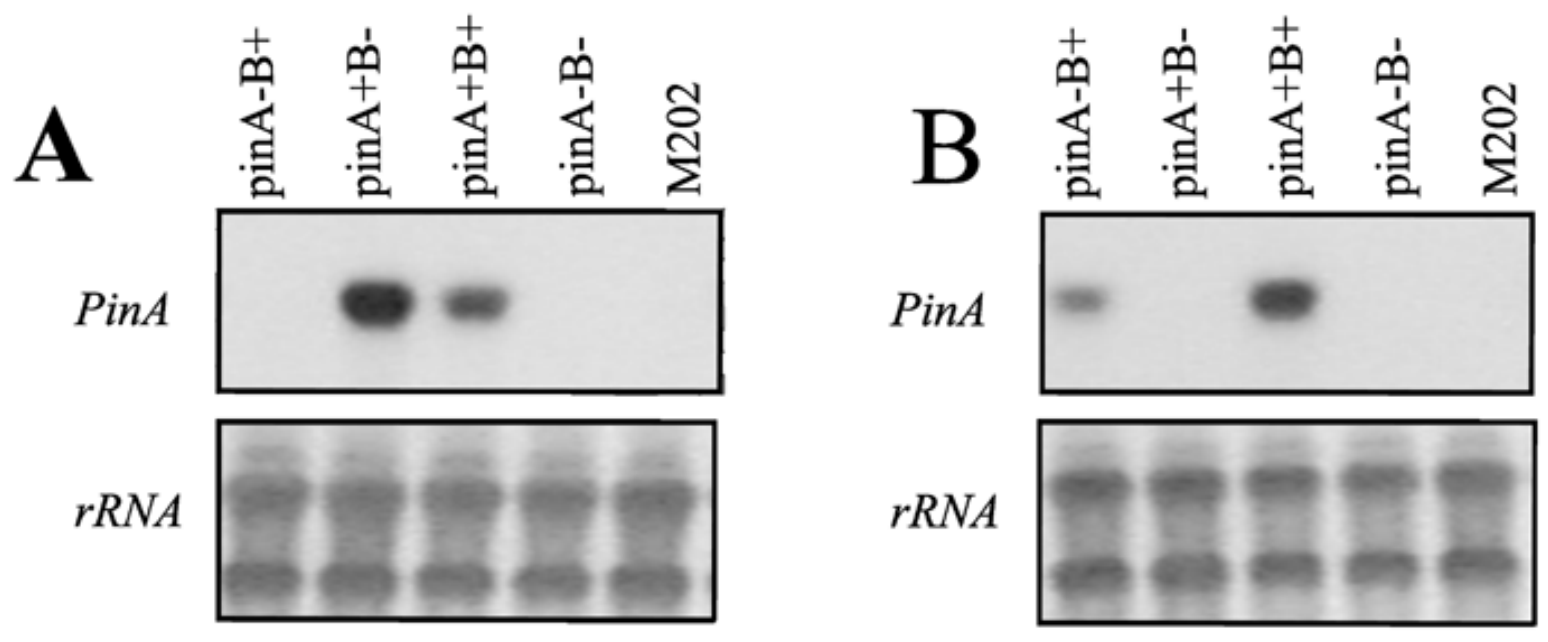

Fig. 1. Expression of pin genes in transgenic rice plants. Northern analysis of puroindoline gene expression in leaves of rice plants. Each lane was loaded with $2 \mu \mathrm{g}$ of total leaf RNA isolated from homozygous $\mathrm{T}_{2}$ plants, size fractionated and hybridized with ${ }^{32} \mathrm{P}$-labeled pinA (left) or pinB (right). Equal loading of RNA was confirmed by stripping and reprobing the membrane with a rDNA probe.
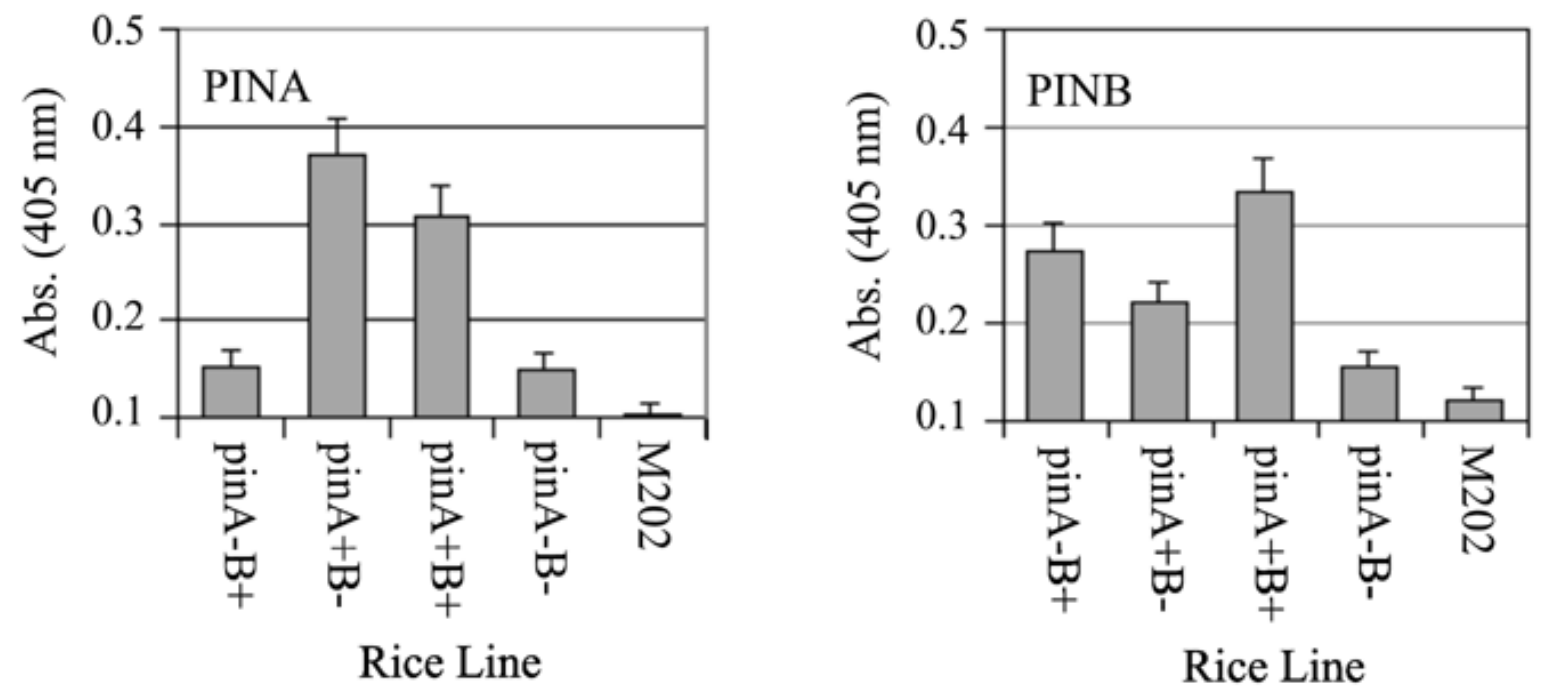

Fig. 2. Enzyme-linked immunosorbent assay (ELISA) analysis of transgenic rice leaf proteins. Each reading represents the average of triplicate ELISAs in which a well was loaded with 200-mg equivalents of total rice leaf extracts prepared via Triton X-114 phase partitioning. Values were determined with PINA-specific antiserum (left) and PINB-specific antiserum (right). 
Although it had been shown previously that the pin genes were expressed in the seeds of these transgenic rice (Krishnamurthy and Giroux 2001), for the purposes of this study it was critical to demonstrate that the pin genes were expressed in the leaves. This was determined by Northern analysis (Fig. 1). Total RNA was isolated from healthy control and transgenic rice leaves with TRIZOL reagent, according to manufacturer's instructions (GIBCO-BRL, Rockville, MD, U.S.A.). Equal amounts of RNA from each sample were loaded in $1 \%$ agarose-formaldehyde gels, electrophoresed, transferred to nylon membranes, and probed with the coding region of $\operatorname{pin} A$ or $\operatorname{pin} B$, as described (Giroux and Morris

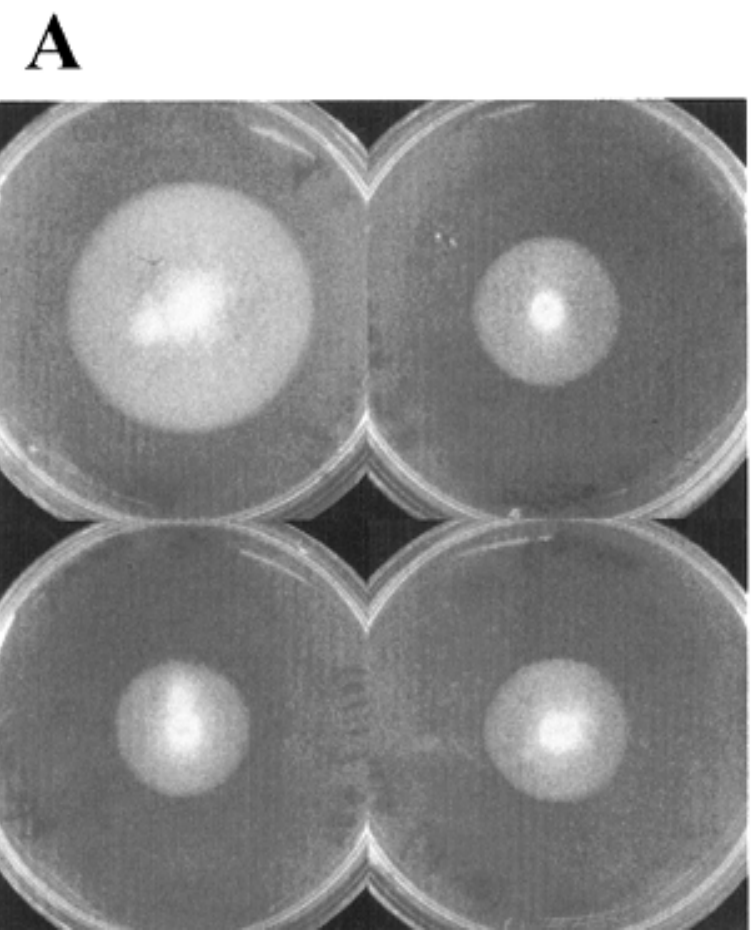

1997). pinA transcripts were identified in the leaves of pin $\mathrm{A}^{+} \mathrm{B}^{-}$and $\operatorname{pin} \mathrm{A}^{+} \mathrm{B}^{+}$, whereas $\operatorname{pin} B$ transcripts were identified in the leaves of pin $\mathrm{A}^{-} \mathrm{B}^{+}$and $\operatorname{pin} \mathrm{A}^{+} \mathrm{B}^{+}$(Fig. 1). In addition, puroindoline transcripts were in seed coats and roots (data not shown).

The puroindoline proteins were detected in the leaves of the $\mathrm{T}_{2}$ transgenic lines by enzyme-linked immunosorbent assays (ELISA), which were performed with polyclonal antibodies raised against PINA- or PINB-specific synthetic peptides designed from the C-terminus sequence of each protein (Krishnamurthy and Giroux 2001). Protein was isolated from rice leaves ground in liquid $\mathrm{N}_{2}$ by Triton X-114 phase parti-

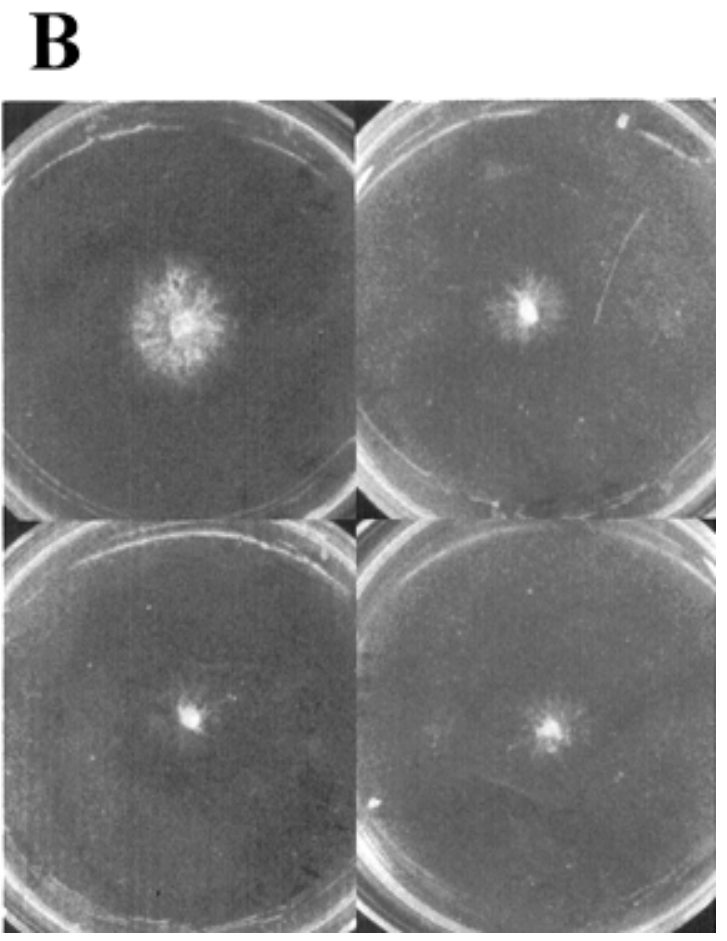

Fig. 3. Growth of A, Magnaporthe grisea and $\mathbf{B}$, Rhizoctonia solani on agar in 5.0-cm petri dishes, to which the leaf extracts of transgenic rice was added. In both, growth in the presence of the extract from pin $A^{-} B^{-}$leaves (upper left), pin $A^{+} B^{-}$(upper right), pin $A^{-} B^{+}$(lower left), and pin $A^{+} B^{+}$(lower right) are shown. $M$. grisea colonies were grown for 5 days on $0.1 \times$ potato dextrose agar (PDA) incubated at $25^{\circ} \mathrm{C}$, whereas the $R$. solani colonies were grown for $24 \mathrm{~h}$ on PDA incubated at room temperature.

Table 1. Effect of extracts from puroindoline-expressing transgenic rice leaves (100 $\mathrm{mg}$ of fresh weight sample) on the radial growth of Magnaporthe grisea and Rhizoctonia solani

\begin{tabular}{|c|c|c|c|c|c|}
\hline \multirow[b]{2}{*}{ Rice lines $^{w}$} & \multirow[b]{2}{*}{$\begin{array}{l}\text { Expressed } \\
\text { genes }\end{array}$} & \multicolumn{2}{|c|}{ Rice blast $^{u}$} & \multicolumn{2}{|c|}{ Sheath blight $^{v}$} \\
\hline & & $\begin{array}{c}\text { Average colony diameter } \\
(\mathrm{cm})\end{array}$ & $\begin{array}{l}\text { Growth inhibition } \\
\qquad(\%)^{x}\end{array}$ & $\begin{array}{c}\text { Average colony diameter } \\
(\mathrm{cm})\end{array}$ & $\begin{array}{c}\text { Growth inhibition } \\
(\%)^{x}\end{array}$ \\
\hline & $\operatorname{pin} A / \operatorname{pin} B$ & & & & \\
\hline M202 & $-1-$ & $2.88 \pm 0.06 \mathrm{a}^{\mathrm{y}}$ & - & $1.50 \pm 0.05 \mathrm{a}$ & - \\
\hline $\operatorname{Pin} A^{-} B^{-}$ & $-1-$ & $2.90 \pm 0.05 \mathrm{a}$ & $-0.63 \pm 3.59 \mathrm{a}$ & $1.52 \pm 0.08 \mathrm{a}$ & $-1.11 \pm 1.92 \mathrm{a}$ \\
\hline $\operatorname{Pin}^{+} B^{-}$ & $+1-$ & $1.85 \pm 0.13 b$ & $35.86 \pm 3.90 \mathrm{~b}$ & $0.76 \pm 0.07 \mathrm{~b}$ & $48.39 \pm 2.79 b$ \\
\hline $\operatorname{Pin}^{-} \mathrm{B}^{+}$ & $-/+$ & $1.88 \pm 0.15 b$ & $34.73 \pm 4.06 \mathrm{~b}$ & $0.88 \pm 0.03 c$ & $41.10 \pm 1.01 \mathrm{~b}$ \\
\hline $\operatorname{Pin}^{+} \mathrm{B}^{+}$ & $+/+$ & $1.86 \pm 0.08 b$ & $35.51 \pm 1.49 b$ & $0.76 \pm 0.05 b$ & $49.48 \pm 1.94 b$ \\
\hline $\mathrm{LSD}^{\mathrm{z}}$ & & 0.16 & 6.72 & 0.11 & 8.71 \\
\hline
\end{tabular}

${ }^{u}$ Triplicate samples measured after 5 days on $0.1 \times$ potato dextrose agar (PDA), in a 5.0-cm petri dish, incubated at $25^{\circ} \mathrm{C}$.

${ }^{v}$ Triplicate samples measured after $24 \mathrm{~h}$ on PDA, in a $5.0-\mathrm{cm}$ petri dish, incubated at room temperature.

${ }^{w}$ All plants are derivatives of rice cultivar M202.

${ }^{x}$ Percent radial growth inhibition compared to M202 control.

${ }^{y}$ Values in a column followed by the same letter are not significantly different (Student's $t$ tests $=P \leq 0.05$ )

${ }^{\mathrm{z}}$ Least significant difference (Student's $t$ tests $=P \leq 0.05$ ). All values were analyzed by Statistical Analysis Systems analysis of variance (SAS Institute, Cary, NC, U.S.A.). Data are the average of three replicates. 
tioning (Giroux and Morris 1998). ELISAs were performed as previously described (Krishnamurthy and Giroux 2001). Whereas the PINA-specific antibody showed very little cross-reactivity with PINB, there was a low level of cross-reactivity between PINA and the antibody raised against PINB. The transgenic lines $\operatorname{pin} \mathrm{A}^{+} \mathrm{B}^{-}$and pin $\mathrm{A}^{+} \mathrm{B}^{+}$were positive for PINA, whereas pin $\mathrm{A}^{-} \mathrm{B}^{+}$and $\operatorname{pin} \mathrm{A}^{+} \mathrm{B}^{+}$were positive for PINB (Fig. 2).

The ability of the PIN expressed in leaves to inhibit fungal growth was examined by extracting the PIN from leaves, as described above for ELISA analysis. The extract from $100 \mathrm{mg}$ of fresh-weight leaf tissue was spread on a 5.0 -cm-diameter petri dish containing potato dextrose agar (PDA; Difco, Detroit, MI, U.S.A.). For each pathogen, triplicate plates were prepared with the extract of each transgenic plant. The center of each plate was inoculated with a small plug of actively growing $M$. grisea or $R$. solani and incubated at $25^{\circ} \mathrm{C}$ or room temperature, respectively. Radial growth was measured periodically, and growth inhibition was calculated (Table 1). The growth of $M$. grisea and $R$. solani (Fig. 3) was inhibited significantly compared with growth on agar alone or agar with the addition of a mock extract or the extract from pin $\mathrm{A}^{-} \mathrm{B}^{-}$ leaves (Table 1). There was no significant differences in the radial growth of either fungus on the three controls. Maximum inhibition of $M$. grisea (35\%) was noted after 5 days of incubation, whereas for $R$. solani, maximum growth inhibition (greater than $40 \%$ ) was seen after $24 \mathrm{~h}$ as a result of the relative growth rates of the two fungi. There were no significant differences in growth inhibition with the extracts from leaves from the different transgenic plants (Table 1). In each case, the percent of growth inhibition decreased as the growth of the control colonies slowed when approaching the edge of the agar.

In order to study the effect of the PIN proteins on fungal disease resistance in rice, triplicate sets of 10 transgenic and control plants were grown in soil in plastic pots, in a growth chamber. This experiment was repeated three times. To analyze rice blast, the four rice genotypes and untransformed control plants were inoculated with $M$. grisea under conditions that favored disease development. An atomizer was used to spray 20-day-old rice plants with a conidial suspension of $M$. grisea $(50,000$ conidia per $\mathrm{ml}$ of $0.5 \%$ gelatin), prepared as described (Mackill and Bonman 1986). Following inoculation, the plants were maintained in a dew chamber, with $95 \%$ relative humidity at 21 to $23^{\circ} \mathrm{C}$, in $16 \mathrm{~h}$ of light and $8 \mathrm{~h}$ of dark. Leaf blast symptoms were scored 7 days postinoculation (dpi), with a scale of 0 to 9 that was developed for rice blast by the International Rice Research Institute (Manila, Philippines). The scale rates disease reaction on the basis of lesion size, shape, and color as well as pathogen sporulation (Leung et al. 1988). Under this system, plants with disease reactions of 0 to 3 are considered resistant, whereas plants with scores of 4 to 9 are susceptible.

Rice blast symptoms began to appear on M202 control and pin $\mathrm{A}^{-} \mathrm{B}^{-}$plants at $3 \mathrm{dpi}$ with $M$. grisea. The onset of symptoms in transgenic lines expressing puroindolines was delayed, beginning on day 4 . At $7 \mathrm{dpi}$, pin $\mathrm{A}^{+} \mathrm{B}^{-}$and $\operatorname{pin}^{-} \mathrm{B}^{+}$exhibited decreased blast symptoms by 46.2 and $29.1 \%$, respectively, compared with wild-type M202 (Table 2). PinA $\mathrm{B}^{+}$showed lower blast disease and significantly higher $(53.5 \%)$ disease control than either of the lines expressing a single pin gene. Pin $\mathrm{A}^{-} \mathrm{B}^{-}$had disease levels comparable to the untransformed control. Generally, small lesions formed on the transgenic lines but did not expand as seen in the control plants (Fig. 4). At 20 days after blast inoculation, disease levels from transgenic and control lines were similar to those observed at $7 \mathrm{dpi}$.

Sheath blight was induced on 30-day-old rice plants by placing an agar block $\left(0.5 \mathrm{~cm}^{2}\right)$ containing $R$. solani mycelium on the base of the sheath surface. As with rice blast, three experiments were performed, each with triplicate sets containing 10 transgenic and control plants grown in soil in plastic pots, in a growth chamber. Plants were maintained in a growth chamber, with $90 \%$ humidity at 22 to $25^{\circ} \mathrm{C}$, with $16 \mathrm{~h}$ of light and $8 \mathrm{~h}$ of dark. At $7 \mathrm{dpi}$, sheath blight symptoms were scored by dividing total lesion length by plant height (Ou 1985).

Sheath blight symptoms began to appear on all plants at $3 \mathrm{dpi}$. At $7 \mathrm{dpi}$, the two lines expressing a single pin gene showed increased tolerance compared with the control plants. Lines pin $\mathrm{A}^{+} \mathrm{B}^{-}$and pin $^{-} \mathrm{B}^{+}$showed 18.8 and $10.6 \%$ reductions in disease, respectively (Table 2 ). As with blast, pin $\mathrm{A}^{+} \mathrm{B}^{+}$, which expresses both pin genes, showed better control than either of the lines with only one gene and had $22.3 \%$ disease control, although this was not significantly higher than pin $\mathrm{A}^{+} \mathrm{B}^{-}$. Whereas increases in tolerance in the transgenic rice were signifi-

Table 2. Suppression of rice blast and sheath blight disease symptoms with puroindoline-expressing transgenic rice

\begin{tabular}{|c|c|c|c|c|c|}
\hline \multirow[b]{2}{*}{ Rice lines $^{s}$} & \multirow[b]{2}{*}{ Expressed genes } & \multicolumn{2}{|c|}{ Rice blast } & \multicolumn{2}{|c|}{ Rice sheath blight } \\
\hline & & Disease incidence $(\%)^{t}$ & Disease control $(\%)^{\mathrm{u}}$ & Disease rating ${ }^{\mathrm{v}}$ & Disease control $(\%)^{\mathrm{w}}$ \\
\hline & $\operatorname{pin} A / \operatorname{pin} B$ & & & & \\
\hline M202 & $-1-$ & $100^{\mathrm{x}} \mathrm{a}$ & - & $35.9 \pm 3.84 \mathrm{a}^{\mathrm{y}}$ & - \\
\hline $\operatorname{Pin} \mathrm{A}^{-} \mathrm{B}^{-}$ & $-1-$ & $98.5 \pm 5.02 \mathrm{a}$ & $1.4 \pm 7.32 \mathrm{a}$ & $35.8 \pm 2.75 \mathrm{a}$ & $-0.18 \pm 5.89 \mathrm{a}$ \\
\hline $\operatorname{Pin} A^{+} B^{-}$ & $+1-$ & $53.7 \pm 5.27 \mathrm{~b}$ & $46.2 \pm 6.94 b$ & $29.1 \pm 3.09 \mathrm{~b}$ & $18.8 \pm 3.87 \mathrm{~b}$ \\
\hline Pin $A^{-} B^{+}$ & $-1+$ & $70.6 \pm 3.57 c$ & $29.1 \pm 8.07 \mathrm{c}$ & $31.9 \pm 2.66 \mathrm{c}$ & $10.6 \pm 4.31 \mathrm{c}$ \\
\hline $\operatorname{Pin} \mathrm{A}^{+} \mathrm{B}^{+}$ & $+/+$ & $46.7 \pm 0.96 b$ & $53.5 \pm 5.35 \mathrm{~d}$ & $27.8 \pm 3.15 b$ & $22.3 \pm 3.50 \mathrm{~b}$ \\
\hline $\mathrm{LSD}^{\mathrm{z}}$ & & 7.55 & 6.12 & 2.06 & 6.17 \\
\hline
\end{tabular}

${ }^{\mathrm{s}}$ All plants are derivatives of rice variety M202.

${ }^{\mathrm{t}}$ Transgenic plants with a susceptible reaction (disease score of 4-9)/susceptible control plants $\times 100$. Means with the same alphabetical letter are not significantly different (Student's $t$ test $=\mathrm{P} \leq 0.05$ ).

u 100 - disease incidence, calculated individually for each replicate before statistical analysis.

${ }^{\mathrm{v}}$ Lesion length/plant height $\times 100$.

${ }^{\mathrm{w}} 100$ - lesion length in transgenic plants/lesion length in control plants $\times 100$, calculated individually for each replicate before statistical analysis.

${ }^{x}$ Each value is the mean of three replicates (10 plants per replicate) from three experiments.

${ }^{y} 100$ - disease rating of transgenic plants/disease rating of M202 control plants $\times 100$, calculated individually for each replicate before statistical analysis.

${ }^{\mathrm{z}}$ Least significant difference (Student's $t$ tests). All values were analyzed by Statistical Analysis Systems analysis of variance (SAS Institute, Cary, NC, U.S.A.). 
cant, the reduction in symptoms was actually more dramatic than the data indicates. The scoring method for sheath blight measures the height of the infected stem divided by total plant height. The distance the lesions moved up the stem was decreased only moderately in the transgenic plants, but the more obvious indication of disease control was the inhibition of lesion spread. Although the lesions in the control plants had coalesced completely by day 7 , when the disease reactions were scored, the lesions in the pin-containing plants were still separate and discrete (Fig. 4). At 20 dpi, symptoms were similar on transgenic and control plants and almost all the plants were dead. Thus, the presence of the puroindolines slowed $R$. solani growth but was unable to completely inhibit its spread under these conditions. With the level of inoculum and disease normally experienced under field conditions, however, the delayed spread of disease may be sufficient to reduce losses significantly.

Several lines of evidence led us to propose that the mechanism for increased disease resistance was the inhibition of fungal growth after infection, not the inhibition of infection itself. First, the PIN extracted from leaves slowed fungal growth, but did not eliminate it. One might then expect that PIN in the leaf might reduce growth of the pathogen following infection rather than eliminate infection itself. Second, when inoculated with $M$. grisea, many small lesions formed but did not expand to form the large lesions on the control plants. An even greater case can be made for inhibited fungal growth with sheath blight where lesions formed in the transgenic plants but expanded more slowly than in the control plants. In these plants, the lesions continued to expand and coalesced by 20 dpi. This had occurred by day 7 in the control plants. The most likely explanation for this is that the puroindoline proteins slowed fungal growth following infection. If expression of the pin genes were actually preventing infection, visible lesions should not have formed at all with rice blast and, presumably, a greater control of sheath blight would have been observed.

It is likely that the differences observed in the control of blast and sheath blight was based on the relative growth rates and different sensitivities of the two fungi to puroindolines. Different sensitivities to puroindolines by several fungi were reported previously during in vitro tests (Dubreil et al. 1998), and we found that the radial growth of $M$. grisea and $R$. solani was inhibited to different degrees when equal amounts of leafextracted PIN was added to agar.

A final observation, consistent with the inhibitory effect of the PIN proteins on fungal growth, is the correlation between pin gene expression and disease tolerance. PinA was more highly expressed in pin $\mathrm{A}^{+} \mathrm{B}^{-}$than $\operatorname{pin} B$ was in $\operatorname{pin} \mathrm{A}^{-} \mathrm{B}^{+}$(Fig. 1 ), and line pin $\mathrm{A}^{+} \mathrm{B}^{-}$consistently showed significantly higher disease control than $\operatorname{pin}^{-} \mathrm{B}^{+}$. Rice line $\operatorname{pin}^{+} \mathrm{B}^{+}$tended to have greater tolerance to both pathogens than either line ex-
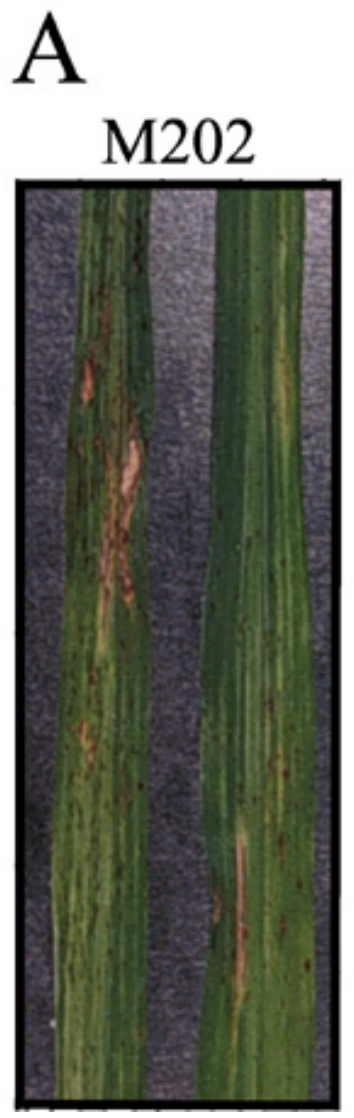
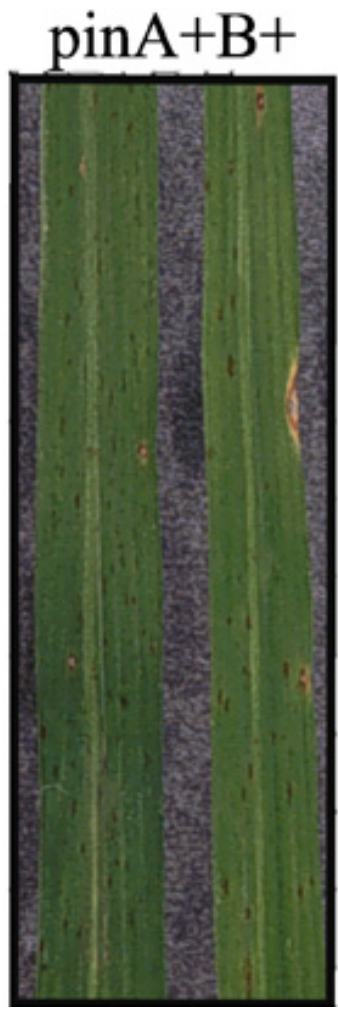
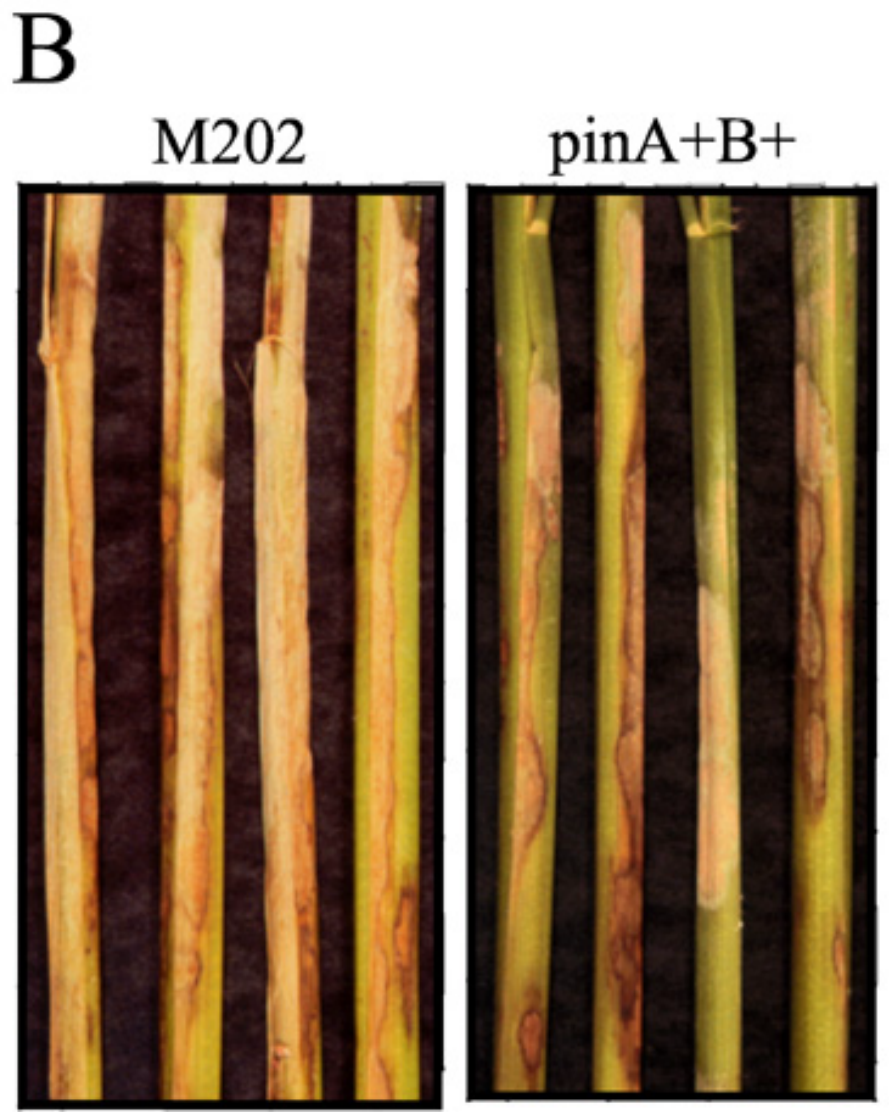

Fig. 4. Disease reactions of transgenic rice. A, Blast disease reaction on control and transgenic plants 7 days after Magnaporthe grisea inoculation. Appearance of disease symptoms on leaves of untransformed M202 control plants (left) and transgenic pin ${ }^{+} \mathrm{B}^{+} \mathrm{T}_{3}$ plants (right). B, Sheath blight disease reaction on control and transgenic plants 7 days after Rhizoctonia solani inoculation. Appearance of disease symptoms on the sheaths of untransformed M202 control plants (left) and transgenic pin ${ }^{+} \mathrm{B}^{+} \mathrm{T}_{3}$ plants (right). 
pressing only one gene. There was no evidence of synergy between the two genes in limiting disease. Although other mechanisms are certainly possible, these results are consistent with the suspected mode of action that PINs act by disrupting fungal membranes, analogous to the modes of action of defensins (Hill et al. 1991; Kagan et al. 1990; Thevissen at al, 1999). Whereas puroindolines share structural similarities as well as in vitro antimicrobial activity with these proteins (Marion et al. 1994; Molina et al. 1993), the puroindolines contain an additional unique tryptophan-rich, lipid-binding domain (Dubreil et al 1998). This may increase the effectiveness of the puroindolines in reducing pathogen growth in transgenic plants.

It is interesting that a protein might be involved in both the protection of wheat seeds from fungal pathogens and a seedquality property like seed hardness. Transformation of rice with the pin genes, which normally have no puroindolines, concomitantly increased seed softness (Krishnamurthy and Giroux 2001) and resistance against two important fungal pathogens. Presumably, the presence of puroindolines in wheat evolved to protect seeds from fungal pathogens but was selected for or against by breeders to produce softer or harder seeds as a result of this secondary property of the puroindoline proteins.

Many of the known antimicrobial proteins such as nsLTPs are in all plants and plant tissues. Therefore, to use these proteins in transgenic plants to effectively limit pathogen growth would require overexpression of the protein. The expression of antimicrobial proteins in plants or plant tissues in which they are not normally produced, as demonstrated here with the pin genes, may have greater potential to limit pathogen infection or growth. Wheat puroindolines were effective as in vivo antifungal proteins in rice, which normally does not produce these proteins. The two most devastating fungal diseases of rice were controlled at significant levels. There is no reason to suspect that similar results could not be achieved with other fungal pathogens of other important crops. Therefore, the incorporation of puroindoline genes could be an effective tool in protecting plants against fungal diseases. Because the puroindolines normally are in wheat endosperm and thus are routinely ingested by humans and animals alike, their use in transgenic crops may be less objectionable than gene products normally not in plants or in the edible portion of plants.

\section{ACKNOWLEDGMENTS}

This work was supported, in part, by USDA-ARS-NRICGP grants 99 01742 and 01-01728, and the Montana Agricultural Experiment Station (MAES Journal Series 2001-38).

\section{LITERATURE CITED}

Beecher, B, Smidansky, E. D., See, D., Blake, T. K., and Giroux, M. J. 2001. Mapping and sequence analysis of barley hordoindolines. Theor. Appl. Genet. 102:833-840.

Broekaert, W. F., Marien, W., Terras, F. R. G., De Bolle, M. F. C., Proost, P., Van Damme, J., Dillen, L., Claeys, M., Rees, S. B., Vanderleyden, J., and Cammue, B. P. A. 1992. Antimicrobial peptides from Amaranthus caudatus seeds with sequence homology to the cysteine/glycinerich domain of chitin-binding proteins. Biochemistry 31:4308-4314.

Broekaert, W. F., Cammue, B. P. A., De Bolle, M. F. C., Thevissen, K., De Samblanx, G. W., and Osborn, R. W. 1997. Antimicrobial peptides from plants. Crit. Rev. Plant Sci. 16:297-323.

Conceicao, A. S., and Broekaert, W. F. 1999. Plant defensins. Pages 247-
260 in: Pathogenesis-Related Proteins in Plants. S. K. Datta and S. Muthukrishnan, eds. CRC Press, Boca Raton, FL, U.S.A.

Datta, S. K., and Muthukrishnan, S. 1999. Pathogenesis-Related Proteins in Plants. CRC Press, Boca Raton, FL, U.S.A.

Dubreil, L., Gaborit, T., Bouchet, B., Gallant, D. J., Broekaert, W. F., Quillien, L., and Marion, D. 1998. Spatial and temporal distribution of the major isoforms of puroindolines (puroindoline-a and puroindoline-b) and nonspecific lipid transfer protein (ns-LTP1e $\mathrm{e}_{1}$ ) of Triticum aestivum seeds: Relationships with their antifungal properties. Plant Sci. 138:121-135.

Fernandez de Caleya, R., Gonzalez-Pascual, B., Garcia-Olmedo, F., and Carbonero, P. 1972. Susceptibility of phytopathogenic bacteria to wheat purothionins in vitro. Appl. Microbiol. 23:998-1000.

Garcia-Olmedo, F., Molina, A., Segura, A., and Moreno, M. 1995. The defensive role of nonspecific lipid transfer proteins in plants. Trends Microbiol. 3:72-74.

Giroux, M. J., and Morris, C. F. 1997. A glycine to serine change in puroindoline $\mathrm{b}$ is associated with wheat grain hardness and low levels of starch-surface friabilin. Theor. Appl. Genet. 95:857-864.

Giroux, M. J., and Morris, C. F. 1998. Wheat grain hardness results from highly conserved mutations in the friabilin components puroindoline a and b. Proc. Natl. Acad. Sci. USA 95:6262-6266.

Hancock, R. E. W., and Scott, M. G. 2000. The role of antimicrobial peptides in animal defenses. Proc. Natl. Acad. Sci. USA 97:8856-8861.

Hill, C. P., Yee, J., Selsted, M. E., and Eisenberg, D. 1991. Crystal structure of defensin HNP-3, an amphiphilic dimer: Mechanisms of membrane permeabilization. Science 251:1481-1485.

Huynh, Q. H., Hironaka, C. M., Levine, E. B., Smith, C. E., Borgmeyer, J. R., and Shah, D. M. 1992. Antifungal proteins from plants: Purification, molecular cloning and antifungal properties of chitinases from maize seeds. J. Biol. Chem. 267:6635-6640.

Johnson, C. W., Carnahan, H. L., Tseng, S. T., Oster, J. J., and Hill, J. E. 1986. Registration of 'M-202' rice. Crop Sci. 26:198.

Kagan, B. L., Selsted, M. E., Ganz, T., and Lehrer, R. I. 1990. Antimicrobial defensin peptides form voltage-dependent ion-permeable channels in planar lipid bilayer membranes. Proc. Natl. Acad. Sci. USA 87:210-214.

Krishnamurthy, K., and Giroux, M. J. 2001. Expression of wheat puroindoline genes in transgenic rice confers grain softness. Nature Biotechnol. 19:162-166.

Leah, R., Tommerup, H., Svendsen, I., and Mundy, J. 1991. Biochemical and molecular characterization of three barley seed proteins with antifungal properties. J. Biol. Chem. 266:1564-1573.

Leung, H., Borromeo, E. S., Bernardo, M. A., and Notteghem, J. L. 1988. Genetic analysis of virulence in the rice blast fungus Magnaporthe grisea. Phytopathology 78:1227-1233.

Mackill, A. O., and Bonman, J. M. 1986. New hosts of Pyricularia grisea. Plant Dis. 70:125-127.

Marion, D., Gautier, M. F., Joudrier, P., Ptak, M., Pezolet, M., Forest, E., Clark, D. C., and Broekaert, W. 1994. Structure and function of wheat lipid binding proteins. Pages 175-180 in: Wheat Kernel Proteins: Molecular and Functional Aspects. S. Martino al Cimino, ed. Universita Degli Studi della Tuscia, Viterbo, Italy.

Molina, A., Segura, A., and Garcia-Olmedo, F. 1993. Lipid transfer proteins (nsLTPs) from barley and maize leaves are potent inhibitors of bacterial and fungal plant pathogens. FEBS Lett. 316:119-122.

Osbourn, A. E. 1999. Antimicrobial phytoprotectants and fungal pathogens: A commentary. Fungal Genet. Biol. 26:163-168.

Ou, S. H. 1985. Rice Diseases, 2nd ed. Commonwealth Mycological Institute, Kew, U.K.

Roberts, W. K., and Selitrennikoff, C. P. 1986. Isolation and partial characterization of two antifungal proteins from barley. Biochem. Biophys. Acta 880:161-170.

Tanchak, M. A., Schernthaner, J. P., Giband, M., and Altosaar, I. 1998. Tryptophanins: Isolation and molecular characterization of oat cDNA clones encoding proteins structurally related to puroindoline and wheat grain softness proteins. Plant Sci. 137:173-184.

Terras, F. R. G., Schoofs, H. M. E., De Bolle, M. F. C., Van Leuven, F., Rees, S. B., Vanderleyden, J., Cammue, B. P. A,. and Broekaert, W. F. 1992. Analysis of two novel classes of plant antifungal proteins from radish (Raphanus sativus L.) seeds. J. Biol. Chem. 267:15301-15309.

Thevissen, K., Terras, F. R. G., and Broekaert, W. F. 1999. Permeabilization of fungal membranes by plant defensins inhibits fungal growth. Appl. Environ. Microbiol. 65:5451-5458. 